\title{
What Heterogeneous Impacts does Internet Finance Have on the Profits of Chinese Commercial Banks?
}

\author{
Bai Wanping* , Su Xinyuan \\ School of Big Data Application \& Economic, Guizhou University of Finance \& Economic, Guizhou \\ Province, China
}

Keywords: Internet finance (ITFIN); Commercial banks; Profits

\begin{abstract}
Since 2012, the Internet finance (ITFIN), as a rising star in the financial industry, has impacted the traditional finance with its unique operating model and market transmission path. Our work explores the role of ITFIN on the profit structure and profitability of commercial banks from a new perspective of market structure. Based on the research on the mechanism of action, we construct an econometric model and conduct an empirical analysis: our panel data model contains the main indicators disclosed by 16 representative commercial banks from 2010 to 2018, including the total asset profit rate and the three major business development data (asset, liability, and intermediary business), and tests the specific impact of ITFIN on the profitability of commercial banks. Our work draws the following conclusions and implications: First, the development of ITFIN will promote the profitability of commercial banks, and it will promote the diversified development of commercial banks' profit structure. Therefore, in the development process, the commercial banks should pay attention to win-win cooperation and develop financial technology, while optimizing market structure and integrating financial resources to promote the optimization of the market economy system. Second, the impacts of ITFIN on the profitability of different types of commercial banks are heterogeneous. It has a greater impact on state-owned commercial banks and joint-stock commercial banks, while it has less or no impact on municipal commercial banks. Therefore, when developing, the commercial banks should actively change their business philosophy, deepen the financial market, reasonably make market positioning and behavioural decisions based on their development, and improve the market competitiveness.
\end{abstract}

\section{Introduction}

At present, the global financial science and technology is entering an era of intelligence, customization and inclusive. Finance, science and technology, Internet, information and other elements are interpenetrate and synergistic. Internet finance (ITFIN) has become an important part of the financial industry. Based on Internet technology (IETF), Internet enterprises can achieve a higher degree of financing, online payment and information transmission channels than traditional financial enterprises, and gradually formed an Internet financial format represented by Internet payment, Internet financial management and network lending. Chinese economy is in a critical period of structural adjustment and transformation. As a rising star of the financial industry, ITFIN affects the traditional finance, which is mainly commercial banking business, with its unique operation mode and market transmission path. It has an impact on the profits of commercial banks that can not be ignored. So, how to measure the impact of ITFIN on the profits of commercial banks? Does the development of ITFIN change the profitability and its structure of commercial banks? Is there heterogeneity among different types of commercial banks (such as state-owned, joint-stock and municipal ones)? The answers to these questions are of great significance to how to maximize the role of ITFIN, how to integrate traditional commercial banks with emerging Internet technologies, and how regulators formulate policies to maintain the orderly and stable development of the financial market.

\subsection{Related literature}

In essence, ITFIN is a financial model based on Internet technology (IETF) and information 
communication technology (ICT) [1]. Scholars' theoretical and empirical research on its definition, development, and its impact on the profitability of commercial banks are still being enriched.

The Internet finance definition first appeared in the literature written by N. Richard [2]. According to the viewpoints of the People's Bank of China (PBoC), most scholars in China define the ITFIN as a new financial business model diferent from traditional financial institutions. The Internet enterprises could achieve financing, payment, investment and information intermediary services by using IETF and ICT. ITFIN is the counterattack of the Internet to the financial industry. It is not a simple addition of IETF and financial industry, but is established on the basis of safe, reliable, mobile and efficient network technology. As its core concept, financial disintermediation can make the flow of funds in the financial market more open and transparent. In three levels, ITFIN embodies characteristics different from traditional finance: first, it has higher service efficiency, including online banking services, third-party payment (TPC), Internet investment fund, etc.; Second, it has different transaction structures, such as antgroup, peer-to-peer lending (P2P), etc.; Third, it renews the financial concepts, such as Bitcoin, Blockchain, etc.

The profitability of commercial banks is one of the important principles of their operation and management, which is the key of their development. It is the driving force for the variety of business scope and the high-quality of customer service. In terms of the factors that affect the profitability of commercial banks, Short [3] classified the factors that affect the profitability of banks into internal and external factors. The former refer to balance sheet and income statement, while the latter mainly include economic environment. Since then, the researches about the factors that affect the profitability of banks are mainly focused on internal or external factors. Among them, Garcia-Herrero [4] compares the profits level of Chinese banking industry with that of international banks from 1997 to 2004, which proves that the profits level of banks with strong capital accumulation capacity is higher. Yu [5] found that the main factors affecting the profitability of Chinese commercial banks are institutional factors. Therefore, in the research in this aspect, the conclusions drawn by Chinese samples are often different from international conclusions, such as Zhao [6], Gao [7], Huang [8] and so on.

Since the emergence of ITFIN, scholars have studied the impact of ITFIN on the profitability of commercial banks from various angles, but have not reached an agreement. According to the international mainstream, the impact of the ITFIN on bank profits is not negative, such as Chande [9], Alexandre [10]. Some views support it has negative influence, such as Geng [11], Momparler [12] and so on. According to Strategic Treasurer and Kyriba [13], the innovation of financial technology is changing the asset allocation structure of commercial banks, and has gradually approached the banking enterprises in terms of market share, which has become the biggest resistance and threat to their business development and profitability. As for Chinese studies, represented by Ba [14], Liang and Shen [15], Gong [16], Guo and Shen [17], the ITFIN and commercial banks can achieve win-win cooperation. They assume that financial enterprises use the Internet financial platform to develop customer resources, improve the efficiency of resource allocation and reduce operating costs; On the other hand, the cooperation between Internet enterprises and financial institutions can also enhance the cross-domain operation ability of enterprises. Studies represented by Qiu [18] and Zheng [19] believe that ITFIN has a negative impact on the commercial banks' earning. They holds that TPC, online financial products and other forms divert a large amount of demand deposits from commercial banks and push down the banks' earning of intermediary business. And the disintermediation of ITFIN also causes the loss of profit sources for commercial banks.

Most of these studies consider that different ITFIN models bring variety impacts on the business model, financial function and operating risk of commercial banks. However, they have not done a systematic analysis on banking structure under the trend of economic and social development, nor formed a complete market transmission path in the discussion on the impact of the development of Internet finance on the profitability of commercial banks. In recent years, although panel model has been used in empirical researches, they mostly based on individual indicators such as assets, liabilities, or intermediary business of commercial banks from different forms of ITFIN. It is not 
based on the complete profit market transmission path of commercial banks yet.

\subsection{Our work}

It can be seen that there are still various contradictions in empirical evidences, and studies have not reached a consensus on whether the impact is positive or negative. The existing literatures show that both sides are reasonable: the development of ITFIN has both positive and negative effects on the profits of commercial banks. It can be considered that the Catfish Effect and Cherry Picking Effect [20] of ITFIN on the profits of commercial banks exist at the same time, and the degree of this influence is related to the characteristics of the banks. Directly, the impact of ITFIN on the banking industry will be reflected in the profitability of commercial banks. Our study differs from the last mentioned studies in two ways following:

First, we start with the perspective of market structure in terms of theoretical analysis. We analyze the influence of ITFIN on the internal product pricing mechanism and product decision mechanism, the external market competitive environment and regulatory environment of commercial banks, and try to explore a complete path of this influence from a new perspective of market structure.

Second, we consider the influence of ITFIN in terms of empirical analysis. We establish a panel data model not only includes macro-economy, industry features and banks' characters, but also contains the Internet financial index, which is published by Wind. Our samples contain 16 commercial banks listed in China before the first year of Chinese Internet Finance era (2013).We focus particularly on different type of the banks, and give a factual evidence that the impact of ITFIN on them are heterogeneous. The results show that the profitability of commercial banks is strongly influenced by the positive effects of ITFIN, and the impact of state-owned and joint-stock commercial banks is more significant than that of municipal ones.

\section{Influence and Mechanism}

In 2007, Chinese ITFIN was born with the establishment of PPDAI, the first online loan platform in China. "The first year of Chinese Internet Finance era." brought by Yu'ebao in 2013, and it marks the beginning of the rapid development of ITFIN in China. The traditional concept of "highend" financial industry will be redefined by Internet technology and close to ordinary users infinitely [21]. In 2016, ITFIN was included in the outline of Chinese 13th five-year Plan, it mark the start of the recognition as a new economic form by Chinese Officials. As the "counterattack innovation" from the Internet to the financial industry in the concept of "Internet +". ITFIN accelerates the evolution of the financial system in the new era, and its profound impact on finance can never be ignored. By 2017, the scale of financial management in Chinese Internet financial industry was 3.15 trillion RMB, an increase of 52.39\% over the same period last year, which only reached $10 \%$ of the remaining balance of 29.54 trillion RMB of banking wealth management products at same time. However, with professionalization, micromanagement and facilitation, the financial management scale is expected to reach 15.5 trillion RMB in 2020, thus it will reach the $70 \%$ level of the existing balance of 22 trillion RMB of banking financial products at same time.

With the development of ITFIN, it has formed a financial model represented by Internet payment, Internet financial management and network lending, and it has penetrated into every involving economic life. Compared with the traditional financial market, ITFIN, which is innovative in multidimension and multi-level, can reduce the degree of information asymmetry between investors and financiers through big data, cloud computation and variety technologies. It changed the market environments of commercial banks and prompt them to change their behaviour to adapt to the volatile external environment.

\subsection{Two-sides impacts}

On the positive side, the development of ITFIN will have a certain Catfish Effect on commercial banks. ITFIN activates the innovation and development momentum of commercial banks in product upgrading, customer service and the financial technology application, and improve the banks' ability of financial efficiency, service quality and risk management. Thus they can improve their 
own market competitiveness, and promote the profitability. According to Li [22], the Internet economy is born to satisfy the Long-tailed of Chinese demand market. The development of ITFIN in China has made full use of Blue Ocean Strategy to create new value and open up incremental market of the Long-tailed. The emergence of ITFIN makes the commercial banks have more diversified business models, more reasonable asset allocation and more accurate service concepts.

On the negative side, the impacts from ITFIN to banks are called Cherry Picking Effect, which make the Internet companies considering higher profits and lower risk when choosing products and cooperative banks. Through the way of investment and cooperation on high-quality assets, the financial magnates can achieve market monopoly, reduce competition, lower the barriers to entry or exit. Furthermore, the profits of commercial banks can be encroached. Figure 1 describes the return on assets (ROA) of Chinese commercial banks from 2011 to 2019 (data from the China Banking Regulatory Commission), It is shown that ROA had drawn a downtrend line during 2011 and 2019. Especially during 2014 and 2017, it reduced by nearly 30\% while ITFIN mushrooming. The most prominent negative impact is the occupation of the banks' asset, liability and intermediary business.

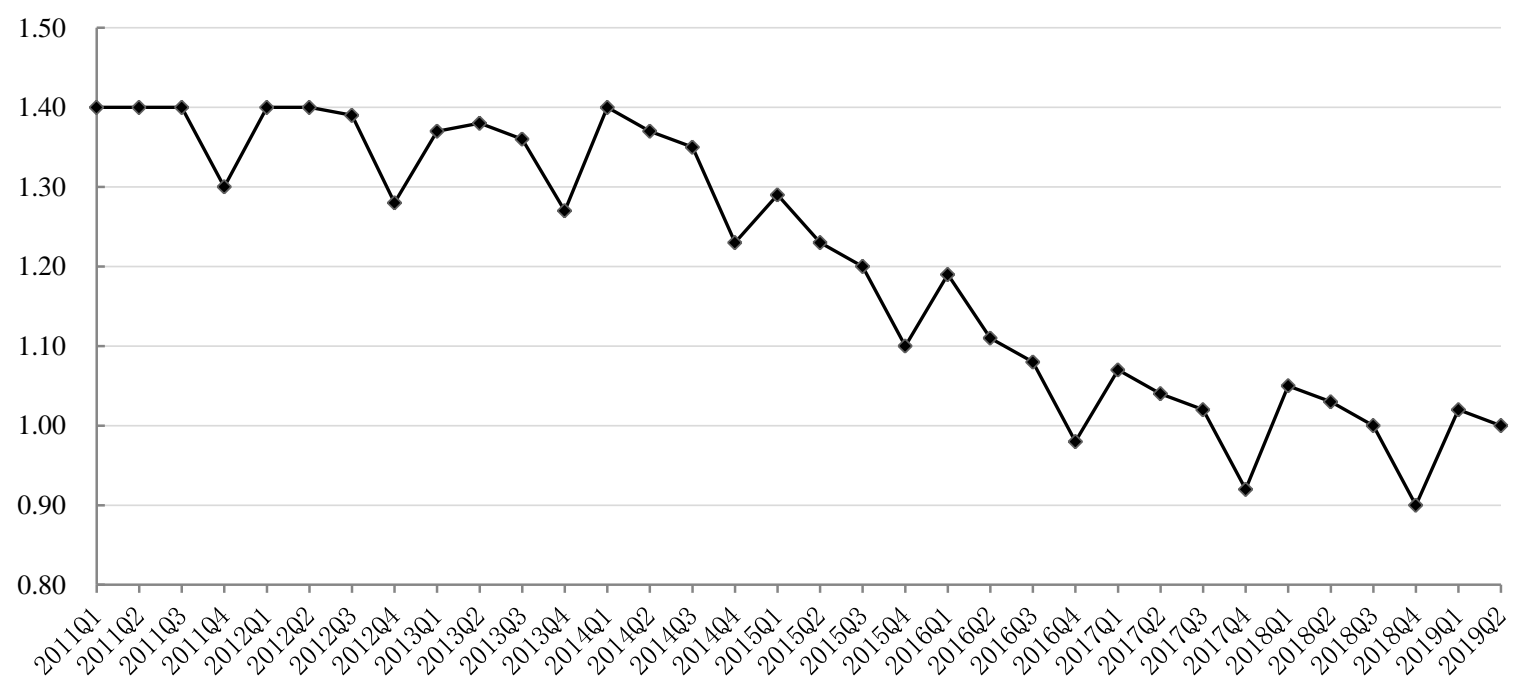

Figure 1 ROA of Chinese commercial banks from 2011 to 2019 (\%).

\subsection{Transmission path}

Because of the system transfer, the economy shunt and the structure adjustment of China in recent years, a multi-level and multi-channel mode has been formed in the way of financial development, which is dominated by the banking industry and supports the development of the real economy. However, commercial banks still have deficiencies in asset structure and asset quality. In recent years, the rapid development of ITFIN has brought a great challenge to the future of commercial banks [23]. According to the traditional industrial organization theory (TIO), market power is the inevitable result of enterprise monopoly, which is an important factor to transmit the loss of social welfare and lead to rent-seeking behavior. According to Xiao and Su [24], the key to the structure adjustment of China is to establish a competitive market structure, break the long-term monopoly pattern of state-owned banks, and set up an efficient resource structure that adapts to the market mechanism. With a unique market structure, ITFIN in China has a distinctive mechanism for the profits of commercial banks. With big data, cloud computation and mobile network technology, ITFIN has developed. It has change the internal and external market structure of commercial banks, which is the hypostatic transmission path of the impacts on banks' profits. The key to making this effect come true is that market strategies, which include development and asset allocation strategies, and services and supervision concepts, are made according to market structure. Thus, the profits of banks will be changed. 


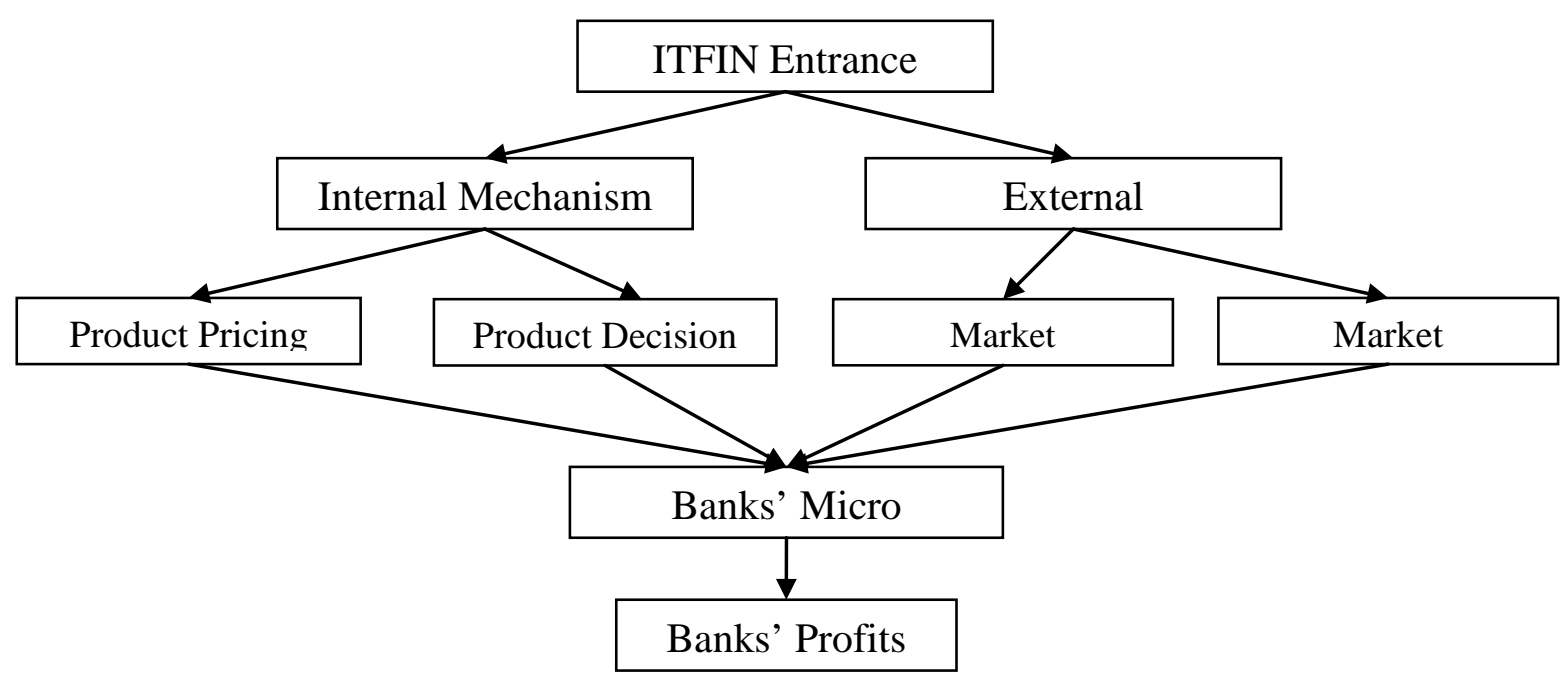

Figure 2 The transmission path of ITFIN's influence on the commercial banks' profits

Figure 2 shows the transmission path of ITFIN's influence on the commercial banks' profits. The entrance of ITFIN has changed the market structure. With the Blue Ocean Strategy, it explored the Long-tailed of Chinese financial market and improved the degree of marketization of interest rates, affected the internal product pricing mechanism and product decision mechanism of commercial banks, formed financial disintermediation through the new platforms such as TPC, promoted the reform of the financial system by doing commercial activities, reduced the standard of entry or exit to change the external market competitive and regulatory environment.

In the process of the development of ITFIN, the positive Catfish Effect and the negative Cherry Picking Effect to the commercial banks are exist at the same time, and are closely related to its degree of development. On one hand, it stimulate banks to take more efficient strategies, Such as improving the resource allocation ability by improving the pricing mechanism of products, form a market-oriented exploitation of products by changing the traditional demands, improve the efficiency of their services and operating by intensifying the competition, and promote the formulation of market regulation policies that supporting their merger and acquisition to let the construction more rational.

\section{Data and Empirical Results}

\subsection{Basic assumptions}

Recent researches indicate that the factors that affect the profits of commercial banks include three aspects: macro-economy, industry features and banks' characters. In addition to them, the development of ITFIN is also an undeniable factor. Based on the theoretical analysis outlined above, we can build a panel data model to quantify and analyse the influence of ITFIN on the profits of commercial banks. To answer the question about how does the profitability and profit structure of commercial banks be affected, we make an assumption below:

H1: With the higher development of ITFIN, commercial banks have stronger profitability and more diversified profits structure.

In 2018, the total assets of Industrial \& Commercial Bank of China (ICBC) have exceeded 27 trillion RMB, while those of small commercial banks generally do not exceed 100 billion RMB. So the differences among the scale of Chinese commercial banks are obvious. Relative to the scale, different commercial banks face to different external environment and make their own strategies in financial market. Relatively speaking, the large-scale banks have complex structures, and there will be a lag in decision-making when they face to the impact of ITFIN. While the small-scale banks are easy to adjust strategies in time to avoid the impact at the same time. According to Ma and Li [25], the large-scale banks are faced with the rigid constraint of national economic environment, and make strategy decisions highly consistent with the governmental policy guidance. On one hand, China is actively promoting the Internet+ plan currently, what makes the enterprises choosing state- 
owned banks and joint-stock commercial banks with large scale. It brings not only the expansion of profit but also the promotion of risk to those banks. On the other hand, in response to changes, large-scale banks could design diversified products based on the scale advantages to avoid the impact of ITFIN. Compared with the small-scale banks, the large-scales have reached the higher level in the stability of the profit system, the ability of operation management and the network technology. Thus, they can be relatively calm when facing to market shocks such as ITFIN. According to Liu, most of the municipal banks are rooted in villages and towns, while the stateowned banks and joint-stock banks running online and offline products simultaneously. The impact from ITFIN depends on Internet technology, which is the shortage of villages and towns. These result in multiple situations to different banks. Based on the analysis above, we make another assumption below:

H2: There is heterogeneity in the impact of ITFIN on the profits of different types of commercial banks.

\subsection{Variables}

Table 1 List of variables

\begin{tabular}{|c|c|c|}
\hline Name & Symbol & Interpretation \\
\hline Profitability of banks & roa $^{1}$ & The return on assets. \\
\hline Profit structure of banks & $\mathrm{prostr}^{1}$ & $\begin{array}{c}\text { Calculated by comprehensively considering the } \\
\text { asset, liability, and intermediary business. }\end{array}$ \\
\hline ITFIN's degree & $\mathrm{intfi}^{2}$ & Internet financial index. \\
\hline Economic development level & $\mathrm{gdpg}^{3}$ & Year-over-year growth of GDP. \\
\hline The stability of economic system & $\mathrm{cpi}^{3}$ & Consumer price index \\
\hline The degree of interest rates liberalization & $\mathrm{dls}^{3}$ & A dummy variable, equalled to zero before 2013. \\
\hline Market structure of banking & $\mathrm{hhi}^{3}$ & Dividing Herfindahl Index by 10000. \\
\hline $\begin{array}{c}\text { The degree of direct financing in stock } \\
\text { market }\end{array}$ & $\mathrm{stock}^{3}$ & Ratio of stock market value to CDP. \\
\hline $\begin{array}{c}\text { The degree of direct financing in } \\
\text { insurance industry }\end{array}$ & $\mathrm{ins}^{3}$ & Ratio of insurance premium income to CDP. \\
\hline Assets scale & $\mathrm{cta}^{3}$ & Logarithm of total assets. \\
\hline Capital adequacy & $\mathrm{car}^{3}$ & Capital adequacy. \\
\hline Operating efficiency & $\mathrm{cir}^{3}$ & Cost-income ratio of bank. \\
\hline Assets structure & $\mathrm{cdr}^{3}$ & Loan-to-deposit ratio of bank. \\
\hline Capital risk level & $\mathrm{npl}^{3}$ & Non-performing loan ratio of bank. \\
\hline
\end{tabular}

Noted that ${ }^{1}$ marks of dependent variables, ${ }^{2}$ marks of independent variables, ${ }^{3}$ marks of control variables.

Table 1 shows the variables and their meanings we chose in the empirical analysis.

\subsubsection{Dependent variables}

In order to quantify the profitability of commercial banks, it is divided into profitability and profits structure.

As for profitability, theoretical analysis shows that there are many indicators that can be selected. According to the research of DeYoung and Rice [26], we choose the return on assets as the evaluation index of the profitability of commercial banks.

As for profits structure, non-interest income ratio is mostly used in the literature. But nowadays, the calculation and analysis based on it are not representative enough. Therefore, we build the profit structure index symbolled by prostr calculated as formula (1), considering the situation of assets, liabilities and intermediary business of commercial banks. Thus we can make an in-depth 
calculation and analysis of the profit structure.

$$
\text { prostr }=\left(\frac{A I}{\text { Asset }}\right)^{2}+\left(\frac{L I}{\text { Liability }}\right)^{2}+\left(\frac{N I}{\text { Businc }}\right)^{2}
$$

Noted that $\mathrm{AI}$ is the income of interest-bearing assets, Asset is the total interest-bearing assets, LI is the income of interest-bearing liabilities, Liability is the total interest-bearing liabilities, NI is the non-interest income, and Businc is the total operating income.

\subsubsection{Independent variables}

The development degree of ITFIN, symbolled by intfi, is the core independent variable of the model. ITFIN is still a new industry in the stage of rapid development, so the academic circles have not reached a unified consensus on the measurement indicators of its level. Considering the representativeness of indicators and the availability of datum, we select the Internet financial index published by Wind database.

\subsubsection{Control variables}

According to the research method of Xing [27] on the profitability of commercial banks, we select control variables both external and internal facts.

The external control variables include two parts: one is the macroeconomic level; the other is the banking level. At the macroeconomic level, choosing the year-over-year growth of GDP to reflect the level of economic development, the consumer price index to reflect the degree of stability of economic system, and a dummy variable to reflect the degree of interest rates liberalization, which is equalled to zero before 2013 and equalled to one after that because of the loosening economic policy on market interest. At the banking level, considering the impact of the degree of banking structure and the direct financing on the banking market environment. We divide Herfindahl Index by 10000 to reflect the market structure of banking. And referring the viewpoint from Yidirim and Philippatos [28] on the degree of direct financing, we choose indicators to measure the development of the stock market and the insurance market. The former is expressed by the ratio of stock market value to GDP, while the latter is expressed by the ratio of insurance premium income to GDP.

As for the internal control variables, they mainly describe the operating conditions of commercial banks, including five variable: the logarithm of total assets reflect assets scale, the capital adequacy, the cost-income ratio of bank reflect operating efficiency, the loan-to-deposit ratio of bank reflect assets structure and the non-performing loan ratio of bank reflect capital risk level..

\subsection{Data source}

Our sample contains 16 commercial banks listed in China before the first year of Chinese Internet Finance era (2013), Table 2 shows the samples include 5 state-owned commercial banks (Industrial and Commercial Bank, China Construction Bank, Agricultural Bank of China, Bank of China, Bank of Communications) and 8 joint-stock commercial banks (China Merchants Bank, China Industrial Bank, Shanghai Pudong Development Bank, China CITIC Bank, China Minsheng bank, China Everbright Bank, Ping An Bank, Huaxia Bank) and 3 municipal commercial banks (Beijing, Nanjing, Ningbo). The datum period is from 2010 to 2018, based on quarterly datum. Deleting some missing samples, 548 valid samples were obtained.

The financial datum of commercial banks and ITFIN's degree are derived from the Wind and Resset database, while the GDP and CPI are derived from the National Statistics Bureau.

Through descriptive statistical and correlation analysis of variables, it can be found that the gap between the maximum and minimum of prostr and roa is obvious, which preliminarily shows that there are differences in profitability and profit structure of different commercial banks. In addition, because the gap between the maximum value and the minimum value of the intfi variable is too large, the natural logarithm of intfi, the lnintfi, is taken in the empirical analysis. 
Table 2 List of sample banks description

\begin{tabular}{|c|c|c|c|c|}
\hline No. & Symbol & Name & Listing Date & Type of bank \\
\hline 1 & $000001 . S Z$ & Ping An Bank & $1991-04-03$ & joint-stock \\
\hline 2 & $002142 . S Z$ & Ningbo Bank & $2007-07-19$ & municipal \\
\hline 3 & $600000 . S H$ & Shanghai Pudong Development Bank & $1999-11-10$ & joint-stock \\
\hline 4 & $600015 . S H$ & Huaxia Bank & $2003-09-12$ & joint-stock \\
\hline 5 & $600016 . S H$ & China Minsheng bank & $2000-12-19$ & joint-stock \\
\hline 6 & $600036 . S H$ & China Merchants Bank & $2002-04-09$ & joint-stock \\
\hline 7 & $601009 . S H$ & Nanjing Bank & $2007-07-19$ & municipal \\
\hline 8 & $601166 . S H$ & China Industrial Bank & $2007-02-05$ & joint-stock \\
\hline 9 & $601169 . S H$ & Beijing & $2007-09-19$ & municipal \\
\hline 10 & $601288 . S H$ & Agricultural Bank of China & $2010-07-15$ & state-owned \\
\hline 11 & $601328 . S H$ & Bank of Communications & $2007-05-15$ & state-owned \\
\hline 12 & $601398 . S H$ & Industrial and Commercial Bank & $2006-10-27$ & state-owned \\
\hline 13 & $601818 . S H$ & China Everbright Bank & $2010-08-18$ & joint-stock \\
\hline 14 & $601939 . S H$ & China Construction Bank & $2007-09-25$ & state-owned \\
\hline 15 & $601988 . S H$ & Bank of China & $2006-07-05$ & state-owned \\
\hline 16 & $601998 . S H$ & China CITIC Bank & $2007-04-27$ & joint-stock \\
\hline
\end{tabular}

\subsection{Econometric model and results}

Based on the analysis above, a Panel Data Model was applied to analyse the impact of ITFIN on the profitability and profits structure if commercial banks. The following formula (2) is used to analyse both the whole datum and the heterogeneity of banks in different types.

$$
\text { (roa, prostr })_{i, t}=\beta_{0}+\beta_{1} \text { lnintf } i_{i, t}+\sum_{k=0}^{n} \beta_{k} X_{i k t}+\varepsilon_{i t}
$$

Where $\mathrm{i}$ and $\mathrm{k}$ are the counter items, t represents time, $\varepsilon$ is an error term, and $\beta$ is the coefficient. Dependent variables are roa and profit. Independent variable is lnintfi. $\mathrm{X}$ are control variables include gdpg, cpi, dls, hhi, stock, ins, cta, car, cdr, cir, and npl.

\subsubsection{Full samples' regression analysis}

First, we need to verify the assumption that with the higher development of ITFIN, commercial banks have stronger profitability and more diversified profits structure. We use the least square method, fixed effect and random effect to regression respectively. F-test and Hausman test were present the setting form of the model was the fixed effect model.

Table 3 Regression results of full samples

\begin{tabular}{|c|c|c|c|c|c|c|c|}
\hline \multicolumn{4}{|c|}{ roa } & \multicolumn{4}{|c|}{ prostr } \\
\hline Variables & $\beta$ (t-test) & Variables & $\beta$ (t-test) & Variables & $\beta$ (t-test) & Variables & \\
\hline lnintfi & $\begin{array}{c}0.000718 * * \\
(2.218)\end{array}$ & ins & $\begin{array}{c}0.0938 * * * \\
(29.77)\end{array}$ & lnintfi & $\begin{array}{c}-0.06194 * * \\
(-3.624)\end{array}$ & ins & $\begin{array}{c}-0.539 * * * \\
(-5.676) \\
\end{array}$ \\
\hline gdpg & $\begin{array}{c}-0.133^{* * *} \\
(-11.68)\end{array}$ & cta & $\begin{array}{c}0.000316^{* *} \\
(2.194)\end{array}$ & gdpg & $\begin{array}{c}2.488 * * * \\
(4.052)\end{array}$ & cta & $\begin{array}{c}0.101^{* * * *} \\
(7.152)\end{array}$ \\
\hline срі & $\begin{array}{c}0.000863 \\
(0.139) \\
\end{array}$ & car & $\begin{array}{c}0.0279 * * * \\
(4.379)\end{array}$ & срі & $\begin{array}{c}0.393 * * \\
(2.138) \\
\end{array}$ & car & $\begin{array}{c}-0.255 \\
(-1.152) \\
\end{array}$ \\
\hline dls & $\begin{array}{c}0.00135^{* * * *} \\
(4.081)\end{array}$ & cdr & $\begin{array}{c}-0.000462 \\
(-0.607)\end{array}$ & dls & $\begin{array}{l}-0.0139 \\
(-1.418)\end{array}$ & $\mathrm{cdr}$ & $\begin{array}{c}0.0963 * * * \\
(3.890)\end{array}$ \\
\hline hhi & $\begin{array}{c}0.123^{* * *} \\
(17.13)\end{array}$ & $\operatorname{cir}$ & $\begin{array}{c}-4.57 e-05 \\
(-0.0215) \\
\end{array}$ & hhi & $\begin{array}{c}-0.834^{* * *} \\
(-2.840) \\
\end{array}$ & cir & $\begin{array}{l}-0.0112 \\
(-0.155) \\
\end{array}$ \\
\hline stock & $\begin{array}{c}-0.00147 * * * \\
(-5.171)\end{array}$ & npl & $\begin{array}{c}-0.0926 * * * \\
(-3.430)\end{array}$ & stock & $\begin{array}{c}-0.00350 \\
(-0.415)\end{array}$ & npl & $\begin{array}{c}11.133^{* * *} \\
(9.612)\end{array}$ \\
\hline Constant & $\begin{array}{c}-0.0346 * * * \\
(-4.237)\end{array}$ & & & Constant & $\begin{array}{c}-2.382 * * * \\
(-4.143)\end{array}$ & & \\
\hline R-squared & 0.8202 & & & R-squared & 0.7851 & & \\
\hline Number of id & 16 & & & Number of id & 16 & & \\
\hline
\end{tabular}

Noted that $* * *, * *, *$ refer to significant correlations at significance levels of $1 \%, 5 \%$, and $10 \%$, respectively. 
Table 3 reports the regression results of full samples. It shows that the development of ITFIN has a significant positive effect on the profitability of commercial banks, and a significant negative decentralized effect on the profits structure. This shows that the development of Internet finance in China has brought diversified changes to the profit structure of commercial banks, as well as a high level of profitability.

\subsubsection{Regression analysis of subgroups}

By means of subgroup regression of state-owned, joint-stock and municipal banks, we analyse the heterogeneity of the impacts on different types of commercial banks.

Table 4 Regression results of subgroups.

\begin{tabular}{|c|c|c|c|c|c|c|}
\hline Variables & \multicolumn{3}{|c|}{ roa } & \multicolumn{3}{|c|}{ prostr } \\
\hline Subgroup & state-owned & joint-stock & municipal & state-owned & joint-stock & municipal \\
\hline $\operatorname{lnintfi}$ & $\begin{array}{c}0.00175^{* * * *} \\
(2.939)\end{array}$ & $\begin{array}{c}0.00108^{* *} \\
(2.219)\end{array}$ & $\begin{array}{c}0.000215 \\
(0.286)\end{array}$ & $\begin{array}{c}-0.06602 * * \\
(-2.427)\end{array}$ & $\begin{array}{c}-0.05394 * * \\
(-2.327)\end{array}$ & $\begin{array}{l}0.00134 \\
(0.0125)\end{array}$ \\
\hline gdpg & $\begin{array}{c}-0.112 * * * \\
(-5.595)\end{array}$ & $\begin{array}{c}-0.106 * * * \\
(-5.576)\end{array}$ & $\begin{array}{c}-0.138 * * * \\
(-5.449)\end{array}$ & $\begin{array}{c}2.260 \\
(0.509)\end{array}$ & $\begin{array}{c}2.804^{* *} \\
(2.708)\end{array}$ & $\begin{array}{c}3.356 * * * \\
(3.500)\end{array}$ \\
\hline срі & $\begin{array}{c}0.00541 \\
(0.498)\end{array}$ & $\begin{array}{c}-0.00321 \\
(-0.354)\end{array}$ & $\begin{array}{c}-0.00273 \\
(-0.190)\end{array}$ & $\begin{array}{l}0.523^{*} \\
(1.906)\end{array}$ & $\begin{array}{c}0.240 \\
(1.148)\end{array}$ & $\begin{array}{c}0.651 \\
(1.252) \\
\end{array}$ \\
\hline dls & $\begin{array}{c}0.00135^{* * *} \\
(2.196)\end{array}$ & $\begin{array}{c}0.00106^{* *} \\
(2.113)\end{array}$ & $\begin{array}{c}0.000842 \\
(1.122)\end{array}$ & $\begin{array}{l}-0.0207 \\
(-1.315)\end{array}$ & $\begin{array}{l}0.00658 \\
(0.575)\end{array}$ & $\begin{array}{c}-0.0731 * * * \\
(-2.747)\end{array}$ \\
\hline hhi & $\begin{array}{c}0.143 * * * \\
(10.73) \\
\end{array}$ & $\begin{array}{c}0.100 * * * \\
(7.209) \\
\end{array}$ & $\begin{array}{c}0.116^{* * *} \\
(6.341) \\
\end{array}$ & $\begin{array}{c}-0.373 \\
(-0.546) \\
\end{array}$ & $\begin{array}{c}-0.915^{* *} \\
(-1.990) \\
\end{array}$ & $\begin{array}{c}-8.244^{* * *} \\
(-5.857) \\
\end{array}$ \\
\hline stock & $\begin{array}{c}-0.00192 * * * \\
(-3.734)\end{array}$ & $\begin{array}{c}-0.00140 * * * \\
(-3.401)\end{array}$ & $\begin{array}{c}-0.00117 * \\
(-1.789)\end{array}$ & $\begin{array}{c}-0.00217 \\
(-0.166)\end{array}$ & $\begin{array}{c}-0.00825 \\
(-0.874)\end{array}$ & $\begin{array}{l}0.0127 \\
(0.542) \\
\end{array}$ \\
\hline ins & $\begin{array}{c}0.0907 * * * \\
(14.36)\end{array}$ & $\begin{array}{c}0.0909 * * * \\
(20.88)\end{array}$ & $\begin{array}{c}0.0874 * * * \\
(12.73)\end{array}$ & $\begin{array}{c}-0.939 * * * \\
(-5.238) \\
\end{array}$ & $\begin{array}{c}-0.442 * * * \\
(-4.324) \\
\end{array}$ & $\begin{array}{c}-0.405 \\
(-1.562) \\
\end{array}$ \\
\hline cta & $\begin{array}{c}0.00109 * * * \\
(3.839)\end{array}$ & $\begin{array}{c}0.00174 * * * \\
(4.768)\end{array}$ & $\begin{array}{c}0.000287 \\
(0.600) \\
\end{array}$ & $\begin{array}{c}0.201^{* * * *} \\
(3.252) \\
\end{array}$ & $\begin{array}{c}0.0937 * * * \\
(3.789) \\
\end{array}$ & $\begin{array}{c}-0.251 * * * \\
(-3.731) \\
\end{array}$ \\
\hline car & $\begin{array}{c}0.0899 * * * \\
(4.994)\end{array}$ & $\begin{array}{c}0.0233 * * \\
(2.397)\end{array}$ & $\begin{array}{l}0.0201 \\
(1.498) \\
\end{array}$ & $\begin{array}{c}-1.454^{* * *} \\
(-2.778)\end{array}$ & $\begin{array}{l}0.0625 \\
(0.245) \\
\end{array}$ & $\begin{array}{c}-0.674 \\
(-1.408)\end{array}$ \\
\hline cdr & $\begin{array}{c}-0.00329 * * \\
(-2.155)\end{array}$ & $\begin{array}{c}-0.000234 \\
(-0.143) \\
\end{array}$ & $\begin{array}{c}-0.000304 \\
(-0.243) \\
\end{array}$ & $\begin{array}{c}0.0534 \\
(1.241) \\
\end{array}$ & $\begin{array}{c}0.223^{* * *} \\
(5.186)\end{array}$ & $\begin{array}{l}-0.0224 \\
(-0.494) \\
\end{array}$ \\
\hline cir & $\begin{array}{c}0.0125^{* * *} \\
(2.801)\end{array}$ & $\begin{array}{c}0.00264 \\
(1.052)\end{array}$ & $\begin{array}{c}0.00426 \\
(1.078)\end{array}$ & $\begin{array}{l}0.341^{* *} \\
(2.272)\end{array}$ & $\begin{array}{l}0.0412 \\
(0.531)\end{array}$ & $\begin{array}{c}-0.317 \\
(-1.386)\end{array}$ \\
\hline npl & $\begin{array}{c}-0.222 * * * \\
(-3.908)\end{array}$ & $\begin{array}{c}-0.288 * * * \\
(-5.352)\end{array}$ & $\begin{array}{l}0.00720 \\
(0.0746)\end{array}$ & $\begin{array}{c}4.978 * * * \\
(2.700)\end{array}$ & $\begin{array}{l}3.279 * * \\
(2.403)\end{array}$ & $\begin{array}{c}-15.00 * * * \\
(-3.110)\end{array}$ \\
\hline Constant & $\begin{array}{c}-0.0837 * * * \\
(-5.536) \\
\end{array}$ & $\begin{array}{c}-0.0689 * * * \\
(-4.481)\end{array}$ & $\begin{array}{l}-0.0252 \\
(-1.217) \\
\end{array}$ & $\begin{array}{c}-6.237 * * * \\
(-3.115)\end{array}$ & $\begin{array}{c}-2.798 * * * \\
(-3.430)\end{array}$ & $\begin{array}{c}8.317 * * * \\
(3.929)\end{array}$ \\
\hline Observations & 178 & 277 & 93 & 178 & 277 & 93 \\
\hline R-squared & 0.853 & 0.8169 & 0.8427 & 0.617 & 0.904 & 0.703 \\
\hline $\begin{array}{l}\text { Number of } \\
\text { subgroup }\end{array}$ & 5 & 8 & 3 & 5 & 8 & 3 \\
\hline
\end{tabular}

Noted that $* * *, * *, *$ refer to significant correlations at significance levels of $1 \%, 5 \%$, and $10 \%$, respectively.

Table 4 reports the regression results of subgroups. We can find that the impacts of ITFIN on different banks are heterogeneous, and the influences on state-owned and joint-stock are greater than municipal ones. Whether of the profitability or profits structure, the influence coefficients of ITFIN on state-owned commercial banks are greater than that of joint-stock banks relatively.

The empirical results present that the profits of commercial banks will be affected by ITFIN, and the positive impact is greater than the negative impact. Due to the differences in market positioning and marketing strategies among the state-owned, joint-stock and municipal banks, the changes in profitability and profits structure are heterogeneous when they faced to the impacts from ITFIN. The impacts of state-owned and joint-stock commercial banks are more significant than that of municipal ones, which is relatively small or even negligible. 


\subsubsection{Robustness check}

In order to check for the validity of the aforementioned findings, we conducted a robustness check. We estimate the alternative profit frontier model. This specification uses the same explanatory variables as the function above and roe as the explained variable. Table 5 reports the regression results of re-estimation. The results are generally consistent with the aforementioned findings, and indicate that the results of this model are reliable.

Table 5 Regression results of re-estimation.

\begin{tabular}{|c|c|c|c|c|}
\hline Variables & \multicolumn{4}{|c|}{ roe } \\
\hline Subgroup & full samples & state-owned & joint-stock & municipal \\
\hline lnintfi & $\begin{array}{c}0.0104^{* *} \\
(2.054)\end{array}$ & $\begin{array}{c}0.0219 * * \\
(2.391)\end{array}$ & $\begin{array}{l}0.0133 \\
(1.623)\end{array}$ & $\begin{array}{c}0.00640 \\
(0.562)\end{array}$ \\
\hline gdpg & $\begin{array}{c}-2.082 * * * \\
(-11.63) \\
\end{array}$ & $\begin{array}{c}-1.807 * * * \\
(-5.882)\end{array}$ & $\begin{array}{c}-1.576^{* * *} \\
(-4.902)\end{array}$ & $\begin{array}{c}-2.069 * * * \\
(-5.373)\end{array}$ \\
\hline срі & $\begin{array}{l}-0.0676 \\
(-0.700)\end{array}$ & $\begin{array}{c}0.119 \\
(0.712)\end{array}$ & $\begin{array}{c}-0.181 \\
(-1.181)\end{array}$ & $\begin{array}{c}-0.343 \\
(-1.574)\end{array}$ \\
\hline dls & $\begin{array}{c}0.00932^{*} \\
(1.804)\end{array}$ & $\begin{array}{c}0.0124 \\
(1.312) \\
\end{array}$ & $\begin{array}{c}0.00196 \\
(0.232) \\
\end{array}$ & $\begin{array}{c}0.0275^{* *} \\
(2.419)\end{array}$ \\
\hline hhi & $\begin{array}{c}1.864 * * * \\
(16.18)\end{array}$ & $\begin{array}{c}2.112 * * * \\
(10.28)\end{array}$ & $\begin{array}{c}1.485^{* * * *} \\
(6.323)\end{array}$ & $\begin{array}{c}2.084 * * * \\
(7.504)\end{array}$ \\
\hline stock & $\begin{array}{c}-0.0211 * * * \\
(-4.761)\end{array}$ & $\begin{array}{c}-0.0266 * * * \\
(-3.372)\end{array}$ & $\begin{array}{c}-0.0204 * * * \\
(-2.922)\end{array}$ & $\begin{array}{c}-0.0184 * \\
(-1.856)\end{array}$ \\
\hline ins & $\begin{array}{c}1.505^{* * *} \\
(30.39)\end{array}$ & $\begin{array}{c}1.271 * * * \\
(13.10)\end{array}$ & $\begin{array}{c}1.523 * * * \\
(20.71)\end{array}$ & $\begin{array}{c}1.433 * * * \\
(13.76)\end{array}$ \\
\hline cta & $\begin{array}{c}0.00590 * * \\
(2.052)\end{array}$ & $\begin{array}{c}0.0152 * * * \\
(3.482)\end{array}$ & $\begin{array}{c}0.0235^{* * *} \\
(3.827)\end{array}$ & $\begin{array}{l}0.0119 \\
(1.633)\end{array}$ \\
\hline car & $\begin{array}{c}-0.280 * * * \\
(-2.720)\end{array}$ & $\begin{array}{c}0.758 * * * \\
(2.739)\end{array}$ & $\begin{array}{c}-0.232 \\
(-1.412)\end{array}$ & $\begin{array}{l}-0.0383 \\
(-0.188)\end{array}$ \\
\hline cdr & $\begin{array}{c}-0.0305^{* *} \\
(-2.485)\end{array}$ & $\begin{array}{c}-0.0748^{* * * *} \\
(-3.193)\end{array}$ & $\begin{array}{c}-0.0515^{*} \\
(-1.862)\end{array}$ & $\begin{array}{l}-0.0254 \\
(-1.334)\end{array}$ \\
\hline $\operatorname{cir}$ & $\begin{array}{c}-0.00951 \\
(-0.271) \\
\end{array}$ & $\begin{array}{c}0.245 * * * \\
(3.562)\end{array}$ & $\begin{array}{c}0.00478 \\
(0.113)\end{array}$ & $\begin{array}{c}0.157 * * * \\
(2.616)\end{array}$ \\
\hline npl & $\begin{array}{c}-2.518 * * * \\
(-5.843)\end{array}$ & $\begin{array}{c}-2.806^{* * *} \\
(-3.211)\end{array}$ & $\begin{array}{c}-4.839 * * * \\
(-5.326)\end{array}$ & $\begin{array}{c}-4.194 * * * \\
(-2.867)\end{array}$ \\
\hline Constant & $\begin{array}{c}-0.344 * * \\
(-2.450)\end{array}$ & $\begin{array}{c}-1.125^{* * *} \\
(-4.841)\end{array}$ & $\begin{array}{c}-0.677 * * * \\
(-2.605)\end{array}$ & $\begin{array}{c}-0.322 \\
(-1.025)\end{array}$ \\
\hline Observations & 548 & 178 & 277 & 93 \\
\hline R-squared & 0.8341 & 0.8575 & 0.8293 & 0.8528 \\
\hline Number of subgroup & 16 & 5 & 8 & 3 \\
\hline
\end{tabular}

Noted that $* * *, * *, *$ refer to significant correlations at significance levels of $1 \%, 5 \%$, and $10 \%$, respectively.

\section{Conclusion and Implication}

Chinese economy is in a critical period of structural adjustment and transformation. as a rising star of the financial industry, ITFIN affects the traditional finance, which is mainly commercial banking business. Our work started with the perspective of market structure in terms of theoretical analysis. We analysed the influences of ITFIN on the internal product pricing mechanism and product decision mechanism, the external market competitive and regulatory environment of commercial banks, and explored a complete path of this influence from a new perspective of market structure. Our work considered the influence of ITFIN in terms of empirical analysis, established a panel data model not only includes macro-economy, banking features and banks' characters, but also contains the Internet financial index.

Our empirical analysis has produced some findings. First, the development of ITFIN has both positive and negative effects on the profits of commercial banks, which generally promotes the profitability and the diversification of their profits structure. Although the profit margins of banks 
have declined in recent years, the decline is not mainly due to ITFIN. Through improving product pricing mechanism, the resource allocation capacity of commercial banks has been improved. By changing the traditional decision-making mechanism, banks can develop into a user-oriented mode. What's more, ITFIN has changed the competition and supervision mechanism of financial market, which makes banks improving their efficiency significantly. Banks should pay more attention to the cooperation with non-bank institutions and enhance their market competitiveness. Second, ITFIN impacts the profits of commercial banks through the hypostatic transmission path, and there is heterogeneity in the degree of different types. We found that there is a great impact on the stateowned and joint-stock commercial banks, while the impact on municipal banks is small or even negligible. This is owing to the reasons following: With large scales, the state-owned and jointstock commercial banks pay more attention to the risk avoidance of investment decisions, and have higher level of operation management ability and network technology. Compared with municipal banks, the large-scales have reached the higher level in the stability of the profit system. Conversely, the businesses of municipal banks are mainly existed in villages and towns, where the web technologies are deficient. And in the increasingly fierce market competition, their external cooperation ability and product innovation ability are weak, it makes the impacts from ITFIN on the profitability and profits structures had been suppressed to a very low degree.

We also draw some implications about the development of the commercial banks in China. First, it requires the enterprise to classify the financial market. Shareholders and management should improve the ability of asset allocation, classify the financial market, and refine product positioning to meet the multiple demands of customers. Second, it requires the FinTech to achieve a win-win condition. Shareholders and management better do follow the high-tech in decision making, cooperate with Internet firms to elevate the level of financial science and technology, and provide customers with more efficient, safe and convenient financial services. Finally, it requires marshalling resources to optimize the banking structure. Companies can promote the formulation of market regulation policies to get the rational construction and improve the mechanism for transmitting monetary policy.

\section{References}

[1] The People's Bank of China. (2015) Guidance on promoting the healthy Development of Internet $\quad$ Finance. 2015-12-14, http://www.pbc.gov.cn/goutongjiaoliu/113456/113469/2813898/index.html.

[2] N.Richard Werthamer, Susan U. Raymond. (1997) Technology and finance: The electronic markets. Technological Forecasting \& Social Change, 55(1).

[3] Short B K. (1979) The relation between commercial bank profit rate and banking concentration in Canada, western Europe and Japan. Journal of Banking \& Finance, 3(3): 209-219.

[4] Garcia-Herrero, A., Gavila, S., and Santabarbara, H. (2009) What Explains the Lower Profitability of Chinese Bank? Journal of Banking and Finance, (1): 2080-2092.

[5] Yu Lixian. (2007) Research on Relationship between the Concentration-ratio and the Profit ability of China’s Banking Industry. Journal of Shanghai Finance University, (04): 21-26.

[6] Zhao Xu, Jiang Zhensheng, Zhou Junmin. (2001) Empirical Study on Market Structure and Performance of China's Banking Industry. Journal of Financial Research, (03): 59-67.

[7] Gao Wei. (2010) Analysis on Profitability of China's Banks. Contemporary Economy \& Management, 32(03): 73-76.

[8] Huang Jinqiu, Qu Xin, Zhang Qiaoyun. (2006) Factors Affecting the profitability of Chinese Commercial Banks. Statistics and Decision, (10): 118-119.

[9] Nikil Chande. (2008) A Survey and Risk Analysis of Selected Non-bank Retail Payments Systems. Bank of Canada, 11(17). 
[10] Alexandre Momparler, Carlos Lassala, Domingo Ribeiro. (2013) Efficiency in banking services: a comparative analysis of Internet-primary and branching banks in the US. Service Business, 12(7): 641-663.

[11] Xianjun Geng, Lihui Lin, Andrew B. (2009) Whinston. Effects of Organizational Learning and Knowledge Transfer on Investment Decisions Under Uncertainty. Journal of Management Information Systems, 26(2): 123-145.

[12] Momparler A, Climent F J, Ballester J M. (2011) The impact of scale effects on the prevailing internet-based banking model in the US. Service Business, (2): 302-314.

[13] Strategic Treasurer, Kyriba. (2019) Fintech Providers are Disrupting the Bank-Led Supply Chain Finance Industry, New Survey Shows. PRNewswire.

[14] Ba Shusong, Shen Peng. (2012) Interaction and Integration: a New Pattern of Competition in the Era of Internet Finance. Rural Credit Cooperative of China, (24): 15-17.

[15] Liang Zhang, Shen Fan. (2013) How State-owned Commercial Banks Deal with the Challenge of Internet Financial Model. New Finance, (07): 47-51.

[16] Gong Xiaolin. (2013) Internet Financial Model and the Influence on Traditional Banking Industry. South China Finance, (05): 86-88.

[17] Guo Pin, Shen Yue. (2015) The Impact of Internet Finance on Commercial Banks’ Risk-taking: Theoretical Interpretation and Empirical Test. Finance \& Trade Economics, (10): 102-116.

[18] Qiu Xun. (2013) Internet Based Fund: Challenges and Enlightenments to Commercial Banks_ A Case Study of YueBao. Journal of Shanghai Finance University, (04): 75-83.

[19] Zheng Zhilai. (2018) Structural Reform of Commercial Banks from the Perspective of Supply Side and Internet Financial Innovation. Reform of Economic System, (01): 130-135.

[20] Detragiache E, Tressel T, Gupta P. (2008) Foreign banks in poor countries: Theory and evidence. Journal of Financial, 63(5): 2123-2160.

[21] Xie Ping, Zou Chuanwei. (2017) How A-Share Listed Industrial Companies Launch Internet Finance Business: 2013 2016. Economy \& Management Publishing House: 4-6.

[22] Li Yaodong, Li Jun. (2014) Internet Finance. Publishing House of Electronics Industry: 147275.

[23] Fan Dalu, Fu Chunqiao, Fan Shiyang, Wu Anhua. (2016) New Changes. China Economic Publishing House: 119-136.

[24] Xiao Jing Su Qin. (2016) Will the Breaking of the Banking Monopoly Ease the Financing Constraints of Small and Medium-sized Enterprises? NanKai Economic Studies, (05): 19-35.

[25] Ma Caoyuan, Li Cheng. (2013) The Efficiency of State-owned Economy, Economic Growth Target Constraint and Monetary Policy Overshoot. Economic Research Journal, 48(07): 76-89+160.

[26] Robert DeYoung, Tara Rice. (2006) Erratum: Noninterest Income and Financial Performance at U.S. Commercial Banks. Financial Review, 41(3).

[27] Xing Tiancai, Sun Jin, Yan Lili. (2013) The Influence of Economic Cycle Strategy on the Profitability of Commercial Banks. Studies of International Finance, (05): 88-96.

[28] Yildirim H S, Philippatos G C. (2007) Restructuring, consolidation and compretition in latin American Banking markets. Journal of Banking and Finance, (31): 629-639. 